\title{
Model Pembelajaran Post-Method Pedagogy Mahasiswa Perguruan Tinggi Seni Pada Mata Kuliah Bahasa Inggris
}

\author{
Yupi Sundari dan Irma Rachminingsih \\ Institut Seni Budaya Indonesia (ISBI) Bandung \\ Jalan BuahBatu No. 212 Bandung
}

\begin{abstract}
The research is aimed at improving students' motivation and achievement toward English subject at STSI Bandung that has been perceived as a difficult and unpleasant subject. The research was conducted at STSI Bandung during English lecture at Karawitan and Fine Art department by using Research and Development Method. The implementation of post-method pedagogy considers three main factors, namely learning environment, student and lecturer. The success of English teaching is influenced by some components, which are student, lecturer, course content and student-lecturer's rapport. The research resulted in a learning model based on post-method pedagogy that puts lecturer as a course-content developer and a class administrator who takes students' characteristics and background into account. In the end of learning activities, the lecturer evaluates the learning outcome and reflects what he or she has done to plan and do the next teaching-learning process.
\end{abstract}

Keywords: post-method pedagogy, English subject, learning model, art students

\begin{abstract}
ABSTRAK
Penelitian ini bertujuan meningkatkan motivasi dan pencapaian studi mahasiswa terhadap mata kuliah bahasa Inggris di STSI Bandung yang selama ini sering dipandang sebagai pelajaran yang sulit dan kurang menyenangkan. Penelitian dilakukan di STSI Bandung pada perkuliahan bahasa Inggris di Jurusan Karawitan dan Seni Rupa dengan menggunakan metode penelitian dan pengembangan atau Research and Development Method. Penerapan post-method pedagogy memperhatikan tiga komponen utama, yaitu lingkungan belajar, siswa dan pengajar. Keberhasilan pengajaran bahasa Inggris dipengaruhi komponen siswa, pengajar, materi ajar dan hubungan antara siswa dan pengajar. Dari penelitian ini didapatkan model pembelajaran post-method pedagogy yang menempatkan pengajar sebagai penyusun materi ajar dan pengelola kelas yang mempertimbangkan karakteristik dan latar belakang pembelajar. Pada akhir kegiatan pembelajaran, pengajar melakukan evaluasi hasil belajar dan merefleksikan apa yang telah dilakukan untuk merencanakan dan melakukan proses belajar mengajar selanjutnya.
\end{abstract}

Kata kunci: Post-method pedagogy, Mata kuliah Bahasa Inggris, Model pembelajaran, Mahasiswa seni. 


\section{PENDAHULUAN}

Penelitian ini didorong oleh dua faktor utama. Pertama, kesadaran akan pentingnya peranan bahasa Inggris sebagai bahasa perantara dalam berbagai aktivitas internasional. Kedua, pengamatan peneliti terhadap pengajaran bahasa Inggris di Indonesia yang belum menunjukkan hasil yang menggembirakan.

Dari beberapa penelitian yang dilakukan, terungkap bahwa penyebab kurang berhasilnya pengajaran bahasa Inggris, diantaranya adalah model pembelajaran yang masih bersifat teacher-centered learning dan tidak menciptakan suasana aktif, kreatif dan menyenangkan di perguruan tinggi mengakibatkan mahasiswa cenderung kurang termotivasi, kurang percaya diri, dan cenderung bergantung pada orang lain (Dirgayasa, dkk., 2007); dan bahwa penguasaan kompetensi bahasa asing sangat dipengaruhi oleh motivasi belajar dan sikap positif siswa (Ehrman, 1996; Gardner 1985, Gardner dan Lambert, 1959, 1972; Noels, et. al., 2000; Ramage, 1990; Tachibana, Matsukawa, dan Zhong, 1996 seperti dikutip dari Suherdi, 2004), serta rasa berdaya diri yang tinggi (Deci dan Ryan, 1992; Pajares, 1996; Pajares dan Miller, 1994, seperti dikutip dari Suherdi, 2004). Dengan demikian, pembelajaran harus dirancang dengan mempertimbangkan karakteristik kelas tempat dosen mengajar untuk mencapai hasil pembelajaran yang diinginkan.

Berkaitan dengan metode pengajaran, perkembangan terkini dalam pengajaran bahasa Inggris menunjukkan bahwa pengembangan model, metode, atau pendekatan 'monolitik' dianggap tidak memadai bagi pelayanan yang adil bagi semua pelajar dalam satu kelas (Kumaradivelu, 1994, 2001; Prabhu, 1990; Shrum dan Glisan, 2000; Rodgers, dalam presentasinya pada TESOL Convention 2001 di St. Luois, Missouri seperti dikutip dari Suherdi, 2004). Kompleksitas permasalahan kelas pada dasawarsa terakhir ini dan kelemahan metode-metode pengajaran bahasa Inggris terdahulu telah mendorong pengembangan pedagogi pasca-metode atau post-method pedagogy (Kumaradivelu, 2001), yang pada dasarnya berupa perangkat prinsip yang digunakan untuk menyelenggarakan pembelajaran yang lebih adil dan diharapkan lebih efektif dalam mengembangkan perilaku para pelajar (Suherdi, 2004).

Permasalahan serupa dalam mata kuliah bahasa Inggris dihadapi oleh mahasiswa di STSI Bandung sebagai salah satu perguruan tinggi seni di Indonesia. Berdasarkan penelitian tim peneliti tahun 2009 dan pengamatan selama PBM berlangsung, motivasi dan pencapaian studi mahasiswa masih rendah. Kelas besar dengan kemampuan mahasiswa yang bervariatif dan bobot mata kuliah praktek yang lebih besar dibandingkan teori, telah menjadi tantangan tersendiri untuk menemukan pendekatan mengajar bahasa Inggris yang tepat. Oleh karena itu, maka pendekatan pembelajaran yang sesuai dengan karakteristik mahasiswa STSI Bandung diperlukan.

Berdasarkan hal tersebut di atas, penelitian ini mencoba merancang model pembelajaran bahasa Inggris yang berorientasi pada pedagogi pasca-metode untuk meningkatkan motivasi belajar mahasiswa dan kualitas proses belajar mengajar mata kuliah bahasa Inggris di Sekolah Tinggi Seni Indonesia Bandung.

\section{METODE}

Metode penelitian yang digunakan dalam penelitian ini adalah metode penelitian pengembangan atau sering 
disebut sebagai Research and Development method (RED). Penelitian ini dilakukan untuk menghasilkan sebuah produk yang akan digunakan dalam dunia pendidikan melalui proses yang ilmiah yang diakhiri dengan tahapan validasi. Prosedur penelitian pengembangan berbentuk siklus agar produk pendidikan yang dihasilkan benarbenar bermanfaat dan sesuai dengan kebutuhan. Perbaikan-perbaikan produk pendidikan dilakukan di dalam tahapantahapan penelitian pengembangan sehingga dapat dihasilkan produk yang paling tidak mendekati ideal. Metode penelitian ini bersifat longitudinal (multi-years) dan digunakan untuk menghasilkan produk tertentu, dan menguji keefektifan produk tersebut (Sugiyono, 2011:407). Metode ini digunakan karena pada akhir penelitian akan menghasilkan sebuah produk berupa sebuah model pembelajaran bahasa Inggris dengan pendekatan post-method pedagogy.

Teknik pengumpulan data dilakukan dengan cara observasi, kuesioner, analisis dokumen, dan wawancara. Observasi yang dilakukan adalah observasi partisipatif. Selama penelitian, peneliti terlibat dengan kegiatan mahasiswa selama PBM berlangsung. Peneliti melakukan pengamatan, memantau dan mencatat apa yang terjadi di dalam kelas selama PBM berlangsung. Kuesioner dibagikan kepada partisipan untuk mendapatkan data empiris terkait gaya belajar siswa. Analisis dokumen dilakukan terhadap hasil observasi dan kuesioner. Wawancara dilakukan secara formal dan informal terhadap mahasiswa yang diambil secara acak dari kedua kelompok kelas. Wawancara informal dilakukan setiap kali selesai pertemuan pembelajaran sementara wawancara formal dilakukan secara intensif pada bulan tertentu yang dipilih. Jenis wawancara yang digunakan adalah semi structured
(Moleong, 2007) untuk mendapatkan informasi yang diperlukan dengan memberi kebebasan kepada partisipan untuk menjawab pertanyaan yang diajukan. Wawancara dilakukan kepada wakil-wakil responden dari setiap kelompok yang diambil secara acak.

\section{HASIL DAN PEMBAHASAN \\ Parameter Post Method Pedagogy}

Post-method pedagogy memiliki tiga parameter, yaitu kekhasan (particularity), kepraktisan (practicality), dan ketermungkinan (possibility). Kekhasan mengacu pada kepekaan guru terhadap situasi dan konteks terkait siswa, tempat, dan waktu pembelajaran berlangsung, untuk menentukan pendekatan pembelajaran yang efektif. Kepraktisan mengacu pada hubungan antara teori dengan praktik. Ketermungkinan mengacu pada identitas individu guru dan siswa, serta kebutuhan mengembangkan metode yang sesuai dengan latar belakang sosial dan budaya mereka. Dengan demikian, penerapan postmethod pedagogy perlu memperhatikan tiga komponen utama, yaitu 1) lingkungan belajar, 2) siswa, 3) pengajar.

Berdasarkan tiga parameter tersebut, maka perancangan model pembelajaran post-method pedagogy pada mata kuliah Bahasa Inggris di STSI Bandung diawali dengan:

a. Mengidentifikasi Karakteristik STSI Bandung

b. Mengidentifikasi Karakteristik Mahasiswa STSI Bandung

c. Menentukan Peran Dosen Dalam Kegiatan Belajar Mengajar dengan pendekatan post-method pedagogy

\section{Karakteristik STSI Bandung}

Sebagai perguruan tinggi seni, STSI Bandung memiliki kurikulum khusus yang 
didasarkan pada kompetensi sarjana seni dengan rumpun mata kuliah: Mata kuliah Pengembangan Kepribadian (MPK), Mata kuliah Keahlian Berkarya (MKB), Mata kuliah Perilaku Berkarya (MPB), dan Mata kuliah Berkehidupan Bersama (MBB). Untuk mencapai kompetensi sarjana seni, terdapat tiga kategori Tugas Akhir mahasiswa, yaitu karya tulis, penciptaan, dan penyajian karya seni. Sejak tahun 2005 sampai sekarang, STSI Bandung meng-gunakan Kurikulum Berbasis Kompetensi (KBK). Mata kuliah bahasa Inggris untuk jenjang S-1 di STSI Bandung diselenggara-kan selama 2 semester (Bahasa Inggris I dan II).

\section{Karakteristik Mahasiswa STSI Bandung}

Informasi mengenai karakteristik mahasiswa STSI Bandung diperoleh melalui: hasil penelitian-penelitian ter-dahulu, observasi, kuesioner, dan wawancara.

Berdasarkan hasil penelitian "Analisis Pencapaian Studi Mata Kuliah Bahasa Inggris (Studi Kasus Mahasiswa STSI Bandung)' oleh Yupi dan Irma (2009), rendahnya pencapaian studi bahasa Inggris

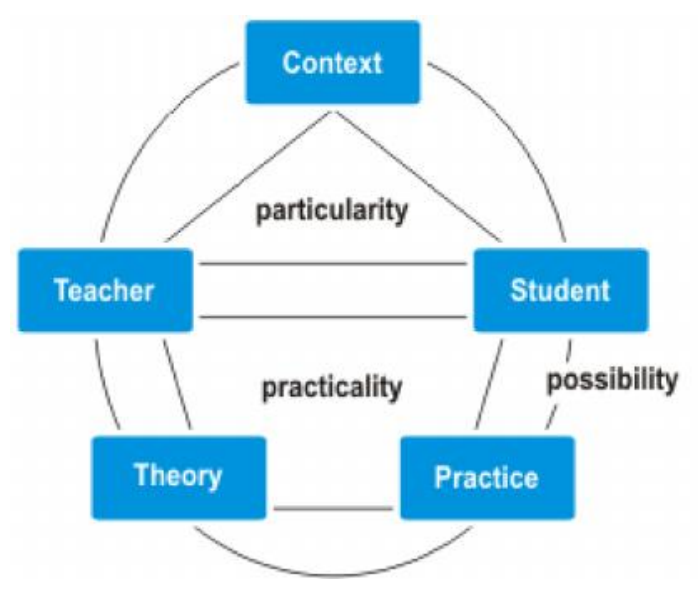

Bagan 1

Tiga parameter post-method pedagogy mahasiswa STSI Bandung dilatarbelakangi oleh faktor-faktor berikut ini: 1) Mahasiswa STSI Bandung merupakan lulusan SMA, SMK, dan MAN dari dalam dan luar kota Bandung yang memiliki kompetensi bahasa Inggris beragam. Mayoritas kompetensi bahasa Inggris mahasiswa yang berasal dari SMK lebih rendah dibanding dengan mahasiswa yang berasal dari SMA; 2) Adanya rehat selama dua atau tiga tahun sebelum melanjutkan pendidikan menyebabkan kebuntuan dalam mengikuti PBM bahasa Inggris terlebih bila selama waktu tersebut, bahasa Inggris tidak pernah disentuh; 3) Rendahnya minat mayoritas mahasiswa ditambah dengan tidak adanya motivasi untuk menguasai bahasa Inggris memunculkan sikap apatis terhadap mata kuliah bahasa Inggris; 4) Ketiadaan dukungan dari lingkungan pertemanan. Rendahnya minat dan motivasi serta sikap apatis mahasiswa membuat mereka lebih suka berteman dengan teman yang "segolongan". Perasaan malu dan rendah diri menyebabkan keengganan membuka diri pada teman-teman yang memiliki kompetensi bahasa Inggris mahasiswa yang lebih baik; 5) Ketiadaan dukungan dari lingkungan orang tua. Rendahnya pendidikan dan kondisi ekonomi orang tua menyebabkan tidak adanya dukungan untuk menguasai bahasa Inggris dengan lebih baik.

Selanjutnya, berdasarkan hasil penelitian studi kasus di STSI Bandung oleh Neneng Yanti, dkk. (2011), mahasiswa STSI Bandung pada umumnya memiliki karakteristik: a) cenderung lebih menyukai kuliah praktek daripada teori; b) mengalami kesulitan dalam membagi waktu antara belajar, menyelesaikan tugas dan latihan praktek karena padatnya aktivitas di luar kelas dengan jadwal latihan berkesenian; c) rendahnya motivasi mengikuti perkuliahan mata kuliah teori; d) memiliki 
tingkat ego yang tinggi sebagai implikasi kreativitas dalam berkesenian; e) cenderung lebih suka bereksplorasi dan bereksperimen.

Selanjutnya hasil observasi terhadap dua kelas (A dan B) yang memperbandingkan pendekatan teacher-centered learning dan student-centered learning menunjukkan hasil yang berbeda. Suasana kelas A yang menggunakan pendekatan teacher-centered learning tampak lebih teratur karena sepenuhnya berada di bawah kendali pengajar. Namun bila pengajar tidak pandai menarik perhatian siswa, misalnya dengan cerita atau gurauan yang relevan dengan materi, perhatian siswa mudah teralihkan. Mahasiswa harus selalu disibukkan dengan materi yang diberikan, karena jika tidak, cenderung mencari kesibukan sendiri, misalnya membuat coretan atau bersenandung.

Adapun, suasana kelas B dengan pendekatan student-centered learning lebih riuh karena siswa dituntut berpartisipasi secara aktif dan bekerja berkelompok. Namun, bila tidak dipantau atau dituntun dengan baik, diskusi kelompok tidak memakai bahasa Inggris, melainkan Bahasa Indonesia dan Sunda. Tanpa tuntunan secara detil, siswa diharapkan dapat menemukan sendiri bagaimana pengetahuan dibangun, tetapi seringkali siswa mengalami kebingungan untuk waktu yang lama.

Dari hasil observasi ini, dapat disimpulkan bahwa pendekatan teacher centered learning (TCL) dan student centered learning (SCL) tidak seharusnya diperbandingkan, dimana pendekatan yang satu dianggap lebih unggul dari lainnya, melainkan menjadi dua pendekatan yang dapat dikombinasikan dan saling mengisi dalam pembelajaran. Dengan pendekatan TCL, dalam memberikan ceramah, pengajar tidak terlalu mendominasi sehingga cenderung membosankan, namun juga memberikan ruang bagi siswa untuk memilih dan memiliki otonomi dalam pembelajaran. Sebaliknya, dengan pendekatan SCL, pengajar tidak membiarkan siswa kebingungan atau kelas berada dalam kekacauan untuk waktu yang lama; pengajar harus tahu kapan harus turun tangan memberikan arahan dan arahan seperti apa yang memungkinkan siswa mencapai pemahaman dengan caranya sendiri.

Dari hasil kuesioner yang disebarkan kepada mahasiswa dapat disimpulkan bahwa mayoritas mahasiswa berasal dari Bandung, mulai belajar bahasa Inggris sejak SD dan berasal dari SMA. Dari data tersebut, dapat diasumsikan bahwa mayoritas mahasiswa sudah memiliki dasar bahasa Inggris yang cukup untuk menerima materi bahasa Inggris tingkat yang lebih tinggi. Namun kenyataannya, sebagian besar mahasiswa tidak menguasai pengetahuan dasar dalam bahasa Inggris, seperti jenis kata dan tenses. Bahkan, ada mahasiswa yang tidak mengetahui arti dan cara pengucapan beberapa kosa kata yang lazim digunakan dalam pelajaran bahasa Inggris di tingkat Sekolah Dasar, misalnya tell dan student (dibaca st dent).

Meskipun mayoritas mahasiswa menunjukkan minat positif terhadap bahasa Inggris, mayoritas mahasiswa juga menganggap sulit dan memerlukan waktu lama untuk menguasai bahasa Inggris. Adapun terkait gaya belajar, secara persentase tidak ada perbedaan signifikan antara gaya belajar visual, auditori maupun kinestetik.

Berdasarkan hasil wawancara terkait konsep belajar bahasa Inggris di Perguruan Tinggi yang ideal yang dilakukan kepada 50 partisipan dari kelas-kelas observasi (A\&B) diperoleh data sebagai berikut: ma- 


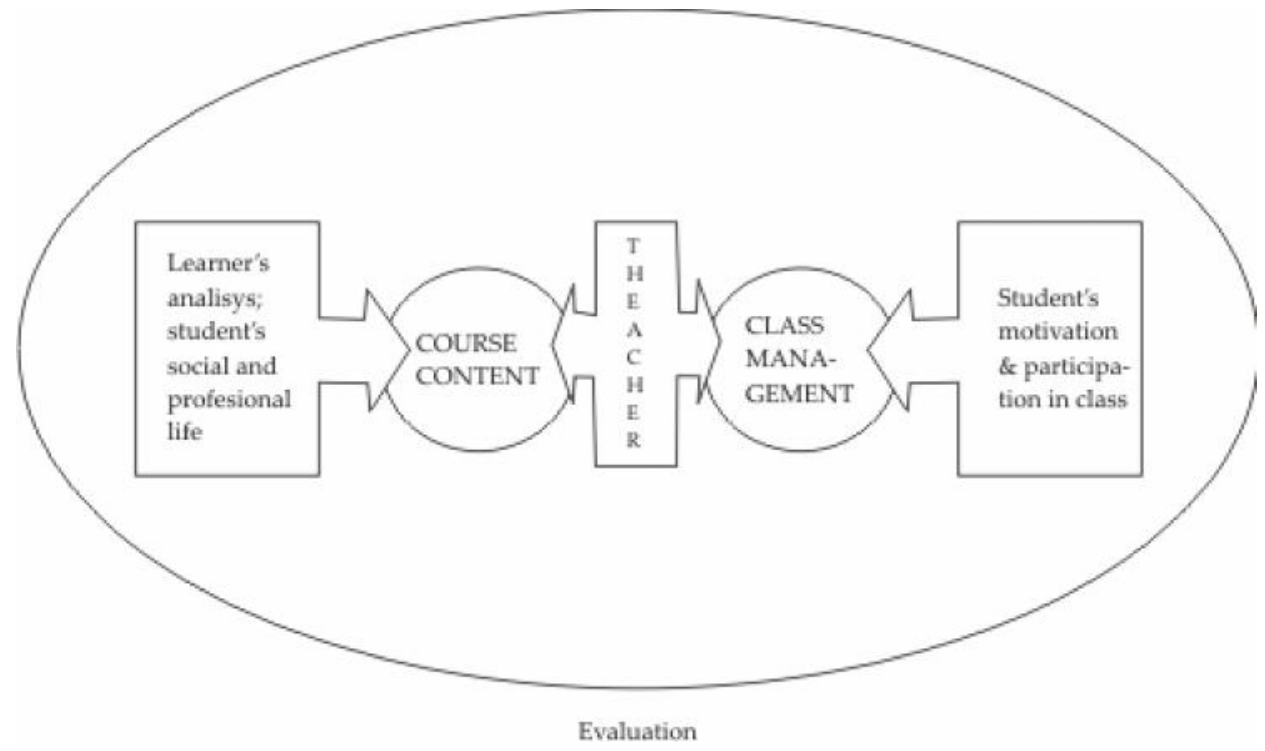

Bagan 2.

Model pembelajaran post-method pedagogy

yoritas responden menginginkan proses pembelajaran dilakukan dalam suasana nyaman dan menyenangkan; penjelasan diberikan dengan sejelas-jelasnya; banyak praktek mendengar, menonton, dan berbicara.

\section{Peran Dosen Dalam Kegiatan Belajar} Mengajar Dengan Pendekatan PostMethod Pedagogy

Setelah mempertimbangkan karakteristik setting dan mahasiswa STSI Bandung, maka dosen dalam kegiatan belajar mengajar dengan pendekatan post-method pedagogy harus mampu berperan sebagai:

\section{1) Motivator}

Mengingat motivasi merupakan salah satu faktor penentu kesuksesan belajar, dosen harus mampu membangkitkan motivasi dan memperbesar keyakinan mahasiswa untuk mampu menguasai bahasa Inggris. Dosen dapat mencari cara membangkitkan motivasi mahasiswa dengan menerapkan teori NLP (Neuro-Linguistic Programming).
2) Pengambil keputusan

Dalam hal ini dosen harus mampu mengkolaborasikan pengetahuan yang dimilikinya terkait pedagogi dan psikologi dalam menghadapi situasi nyata di kelas dan menentukan teknik atau pendekatan yang paling sesuai untuk diterapkan.

\section{3) Navigator}

Dosen menentukan arah pencapaian pembelajaran menuju kompetensi komunikatif.

4) Fasilitator

Dosen memfasilitasi mahasiswa untuk dapat menggali kemampuannya dalam berbahasa Inggris.

\section{5) Peneliti}

Dalam hal ini dosen memantau dan mencatat apa yang terjadi di dalam kelas selama proses belajar mengajar. Selanjutnya mengevaluasi dan merefleksikan apa yang telah dilakukan untuk merencanakan dan melakukan proses belajar mengajar selanjutnya. 
Tabel 1: Tahapan Penerapan Model

\begin{tabular}{cc}
\hline \multicolumn{1}{c}{ Penyusunan Bahan Ajar } & Pengelolaan Kelas \\
\hline$\square$ Mengidentifikasi karakteristik siswa & Mengidentifikasi karakteristik siswa \\
$(5 \mathrm{~W}+1 \mathrm{H})$ & meliputi minat, motivasi, sikap, gaya \\
$\square$ Mencari tahu latar belakang siswa terkait & belajar dan partisipasi di kelas \\
kehidupan sosial dan profesional; & Menentukan peran dosen dalam KBM; \\
$\square$ Mengidentifikasi kebutuhan siswa; & Menerapkan metode -metode tertentu \\
$\square$ Mengadopsi, mengadaptasi, memilih, & dalam menyampaikan bahan ajar-bahan \\
mengembangkan dan membuat bahan & ajar tertentu berdasarkan latar belakang \\
ajar bahasa Inggris yang sesuai; & dan karakteristik siswa; \\
\hline
\end{tabular}

Keterangan: Pada akhir kegiatan pembelajaran, pengajar melakukan evaluasi hasil belajar dan merefleksikan apa yang telah dilakukan untuk merencanakan dan melakukan proses belajar mengajar selanjutnya.

\section{Perancangan Model}

Perancangan model pembelajaran dengan pendekatan post-method pedagogy dilakukan dengan:

1. Mengidentifikasi hubungan antara konteks, pengajar dan siswa

2. Mengidentifikasi konteks terkait kehidupan sosial dan profesional siswa

3. Mengidentifikasi kebutuhan siswa terkait konteks

4. Mengidentifikasi kemampuan berbahasa Inggris siswa

5. Mengidentifikasi kesalahan umum yang sering atau berulang-ulang dilakukan siswa terkait bahasa Inggris

6. Mengadopsi, mengadaptasi, memilih, mengembangkan dan membuat isi bahan ajar (course content) bahasa Inggris yang sesuai dengan gaya belajar dan kebutuhan siswa

7. Mengidentifikasi karakter siswa terkait motivasi dan partisipasi

8. Mengidentifikasi hubungan antara pengajar dengan siswa yang berpengaruh terhadap keberhasilan pengajaran
Komponen:

$\square$ Learner's analysis; student's social and professional life:

Analisa pembelajar; Kehidupan sosial dan profesional siswa

- Kehidupan sosial yaitu latar belakang budaya dan lingkungan sosial siswa; kehidupan sehari-hari siswa

- Kehidupan profesional yaitu bidang studi/profesi yang dipilih siswa

Course content: Materi ajar

$\square \quad$ Teacher: Pengajar

$\square \quad$ ClassManagement: Pengelolaan kelas

$\square \quad$ Student's motivation and participation in class: Motivasi dan partisipasi siswa di kelas

Evaluation: Evaluasi

\section{SIMPULAN}

Pada dasarnya, di era post-method pedagogy ini, timbul kesadaran bahwa tidak ada satu pun metode pengajaran bahasa yang merupakan metode terbaik. Metodemetode pembelajaran tertentu dapat dimanfaatkan secara maksimal sesuai 
dengan kondisi kelas tertentu, sehingga satu metode tunggal bukan lagi faktor kunci kesuksesan atau kegagalan pembelajaran bahasa. Pendekatan post-method pedagogy ini memungkinkan dosen mengembangkan kreatifitasnya berdasarkan karakteristik kelas yang diajar untuk mencapai kompetensi yang telah ditentukan pada kurikulum yang digunakan.

Keberhasilan pengajaran bahasa Inggris terutama dipengaruhi komponen: siswa, pengajar, materi ajar, hubungan antara siswa dan pengajar. Dari penelitian ini didapatkan model pembelajaran postmethod pedagogy yang menempatkan pengajar sebagai penyusun materi ajar dan pengelola kelas yang mempertimbangkan karakteristik dan latar belakang pembelajar. Materi ajar dirancang dengan mempertimbangkan kehidupan sosial dan profesional siswa sehingga memungkinkan siswa terpapar dengan dunia nyata. Dengan demikian diharapkan pembelajaran terasa lebih bermakna dan berdampak terhadap kehidupan siswa di luar kelas. Sedangkan dalam mengelola kelasnya, dosen bisa berperan sebagai motivator, pengambil keputusan, navigator, fasilitator dan peneliti. Pada akhir kegiatan pembelajaran, pengajar melakukan evaluasi hasil belajar dan merefleksikan apa yang telah dilakukan untuk merencanakan dan melakukan proses belajar mengajar selanjutnya.

\section{Daftar Pustaka}

Alemi, M dan P. Daftarifard

2010 "Pedagogical Innovations in Language Teaching Methodologies". Journal of Language Teaching and Research, Vol. 1, No. 6, pp. 765-770, November. Finland: Academy Publisher.

Baharuddin

2007 Psikologi Kependidikan. Jogjakarta: ArRuzz Media.
Brown, H.D.

2007 An Interactive Approach to Language Pedagogy: $3^{\text {rd }}$ edition. Pearson Education ESL.

Crider, J.

2006 On Teaching Writing: A Handbook, $3^{\text {rd }}$ printing. USA: Christian Light Publications, Inc.

DePorter, B \& M. Hernacki

1992 Quantum Learning: Unleashing the Genius In You. New York: Dell Publishing.

DePorter, B \& M. Hernacki

2013 Quantum Learning: Membiasakan Belajar Nyaman \& Menyenangkan. Bandung: Kaifa.

Didi Suherdi

2004 Efektivitas Model Pembelajaran Berorientasi Kompetensi Berbasis Interaksi Afeksionat (MAKBIA) Dalam Meningkatkan Mutu Hasil Belajar Bahasa Indonesia: Sebuah Studi Eksperimental Kuasi dalam Pembelajaran Bahasa Indonesia di SLTP KORPRI Unit Universitas Pendidikan Indonesia. Disertasi. Program Pasca Sarjana Universitas Pendidikan Indonesia.

Johnson, J.

2004 A philosophy of second language acquisition. New Haven: Yale University Press.

Kumaravadivelu, B.

2006 Understanding language teaching: From method to postmethod. New Jersey: Lawrence Erlbaum Associates, Publishers.

Rusman

2012 Model-model Pembelajaran: Mengembangkan Profesionalisme Guru. Jakarta: Rajawali Pers.

Siusana Kweldju

2002 Pengajaran Bahasa Inggris Berbasis Leksikon: Sebuah Alternatif yang Tepat untuk Pengajaran Bahasa Inggris di Indonesia. Pidato Pengukuhan Guru Besar dalam Bidang Kosa Kata. Disampaikan pada Sidang 
terbuka Senat Universitas Negeri Malang, 3 Oktober 2002.

Snow, A. M \& L. Kamhi-Stein

2006 Developing a New Course for Adult Learners. Maryland USA: TESOL, Inc.

Sri Utari N. Subyakto

1988 Metodologi Pengajaran Bahasa. Jakarta: Departemen Pendidikan dan Kebudayaan, Dirjen Dikti P2LPTK.

Totok Pdy

2013 Buku Saku NLP. Yogyakarta: Pohon Cahaya.

\section{Sumber lain:}

B. N. Ningrum

2013 Pengaruh Lingkungan Belajar \& Motivasi Belajar Terhadap Prestasi Belajar Mata Pelajaran Ekonomi Siswa Kelas XI di MAN Keboan Tahun Pelajaran 2012-2-13.

Kumaravadivelu, B.

1994 The postmethod condition: Emerging strategies for second/foreign language teaching. TESOL Quarterly, 28(1), 27-48.

Kumaravadivelu, B.

2001 Toward a postmethod pedagogy. TESOL Quarterly, 35(4), 537-560.
Kumaravadivelu, B.

2003 A postmethod perspective on English language teaching, World Englishes, 22(4), 539-550.

M.A. Ridho

2012 Pengaruh Lingkungan terhadap Motivasi Belajar dan Dampaknya terhadap Prestasi Belajar Siswa Kompetensi Keahlian Audio Video SMK Muh. Kutowinangun Kebumen. http://eprints.uny.ac.id/ 9632/1/JurnalMuhAkbarRidho_ 05502241022_Dr_Putu_Sudira.pdf

N. S. Prabhu

1990 There is no best method - why? TESOL Quarterly, 24(2), 161-176.

Partono \& Tri Minarni

2006 Pengaruh Disiplin E Lingkungan Belajar terhadap Prestasi Belajar Mata Pelajaran Ekonomi. http://journal.unnes.ac.id/ nju/index.php/DP/article/download/ 474/434 (accessed 5/5/2014)

Rogers, $\mathrm{T}$.

2000 Methodology in The New Milennium. English teaching Forum Online, 28(2). http://exchanges.state.gov/ englishteaching/forum/archives.html (accessed 21/11/2012). 